\title{
10. CONIACIAN/SANTONIAN DEPOSITIONAL ENVIRONMENT ON THE RIO GRANDE RISE AS EVIDENCED FROM CARBONATE SEDIMENTS AT HOLE 516 ${ }^{1}$
}

\author{
John D. Milliman, Woods Hole Oceanographic Institution, Woods Hole, Massachusetts
}

\section{PETROGRAPHIC ANALYSIS}

Petrographic analysis of the Coniacian/Santonian sediments lying above the volcanic basement on the Rio Grande Rise (Hole 516F) reveals a rapidly increasing water depth with cessation of volcanism. While the carbonate particles in this sedimentary sequence cannot individually be used as exact indicators of water depth, the composite nature of the particles can, in most cases, indicate the general environment of deposition and postdepositional alteration.

The deepest sample, Sample 516F-126-1, 37-39 cm comes from the volcanic basement itself and as such consists of a mixture of fractured volcanic rock and carbonate sediment. The carbonate sediment is dominated by matrix containing a combination of shallow-water carbonate fragments (coralline algae, mollusk shells, echinoid fragments, benthic foraminifers) and lithoclasts (Plate 1, Fig. 1); one superficial ooid was noted. ${ }^{2}$ Most of the lithoclasts are well rounded, indicating significant abrasion prior to deposition. The carbonate particles in this section tend to be recrystallized and micritized, particularly the mollusk fragments, many of which are highly bored. The carbonate sediment is cut with veins that are filled with what appears to be iron-rich material. The overlying carbonates in Sample 516F-126-1, $0-4 \mathrm{~cm}$ are very similar in character, but they occur as vein fillings within fractured volcanic rock.

The abundance of coralline algae and other highly altered, shallow-water carbonate grains suggests shallowwater deposition and alteration. Water depth presumably was less than $50 \mathrm{~m}$, very possibly less than $20 \mathrm{~m}$. The micritic matrix that binds the sediments indicates a quiescent depositional environment (Plate 1, Fig. 1). Such low energy would be expected in the vein fillings (Sample 516F-126-1, 0-4 cm), but the underlying carbonate sediment (Sample 516F-126-1, 37-39 cm) is equally fine grained (Plate 1, Fig. 3); possibly this sediment was deposited in a quiet, shallow environment, such as the shallow subtidal leeward of islands.

In Sample 516F-125-2, 11-14 cm, the biogenic fragments are surrounded by rim cement, and the pores filled with large crystal spar (Plate 1, Fig. 4). These properties

\footnotetext{
${ }^{1}$ Barker, P. F., Carlson, R. L., Johnson, D. A., et al., Init. Repts. DSDP 72: Washington (U.S. Govt. Printing Office).

2 Some of the lithoclasts consist of vesicles filled with calcite in a geoidal fashion, thus appearing similar to ooids, even to the extent of displaying an interference cross under polarized light (Plate I, Fig. 2). The small size of the individual "ooids" ( $30-70 \mu \mathrm{m})$, plus the geoidal manner of growth (as opposed to concretionary) indicates that they are not ooids.
}

and the lack of depositional matrix suggest deposition within a higher-energy environment. This is also suggested by the micritic envelopes around a great many of the mollusk fragments (Plate 1, Fig. 5), indicative of long-term exposure to surrounding waters-that is, fairly slow rates of accumulation and considerable sediment mixing. The biogenic particles are similar to those in Core 126: coralline algae, benthic foraminifers, echinoids, and mollusk shells. Thus it is assumed that these sediments were deposited in a fairly shallow-water (20$50 \mathrm{~m}$ ), high-energy environment; an open shelf (therefore somewhat deeper than the waters in Core 126) is not an unreasonable guess. The complete lack of terrigenous volcanic grains in this horizon is a bit puzzling, because volcanic detritus shows up in younger overlying sediments (Core 124); clearly, however, during accumulation of this sequence, no influx of volcanic material occurred.

Sediments in Sample 516F-124-2, 64-70 cm contain more matrix. Some grains are filled with glauconite (Plate 1, Fig. 6). Such petrographic properties indicate deposition and diagenesis in lower-energy, deeper waters, although the presence of shallow-water benthic organisms (coralline algae, mollusks, benthic foraminifers) point to depths no greater than 100 to $150 \mathrm{~m}$. An outer shelf-upper slope environment (explaining the glauconite) is suggested.

Sample 516F-124-1, 11-14 cm contains some fragments of benthic organisms (mollusks-particularly the prismatic structures of Inoceramus - and hyaline foraminifers) but is dominated by planktonic foraminiferal shells within a very fine-grained matrix. The colors are mottled, as if burrowed, and a number of large phosphorite grains are seen, as are manganese coatings and in-fillings. Some of the rock has recrystallized mosaic calcite rather than micritic matrix, and veins of sparry calcite are common. The mixture of shallow-water benthic organisms and planktonics can indicate either deposition on the slope (upper?) or the downslope transport of shallow water sediment (via slump, turbidity currents?) and mixing with deeper water material.

In Sample $516 \mathrm{~F}-123-1,8-10 \mathrm{~cm}$, the sediment is dominantly bedded planktonic foraminiferal ooze. However, some layers contain patches with greater amounts of planktonic foraminifers, echinoids, and mollusk and Inoceramus fragments. Clearly the depositional environment was quiet deep water, with outside introduction of shallower-water material. The apparent absence of graded bedding, however, argues against turbidite deposition. 


\section{SUMMARY OF DEPOSITIONAL ENVIRONMENTS}

Sediments in the lower sections of Hole 516F show a classic sequence of sediment deposited within progressively deepening waters. The bottom-most sediments clearly accumulated in shallow depths, as suggested by the presence of photosynthetic coralline algae. The presence of matrix indicates low energy, reflecting either the local absence of currents within the fractures of volcanic rocks or very shallow waters leeward of islands. It is possible that the water depths were less than $10 \mathrm{~m}$ and certainly less than $50 \mathrm{~m}$. In Core 125 , although the coralline algae again indicate shallow photosynthetic depths, the lack of matrix points to higher energy, perhaps an open shelf, thereby suggesting somewhat deeper waters. In the lower part of Core 124, the depth of deposition probably was outer shelf or upper slope (100-150 m); in the upper part of this same core, the depth appears to be mid-slope, possibly deeper if the shallow-water grains were introduced by way of downslope flow. Finally, in
Core 123 , the sediment is truly deep water, with only sporadic amounts of shallow-water material, possibly introduced by some gravity-induced down-slope movement; a water depth of 1000 to $2000 \mathrm{~m}$ would not seem unreasonable.

This continually increasing water depth clearly reflects the gradual subsidence of the Rio Grande Rise relative to sea level, from nearly the intertidal in the oldest sediments to neretic-bathyal in Core 123 . Subsidence does not appear to have been uniform: sediments in the lower 5 to $10 \mathrm{~m}$ represent deposition in depths less than $100 \mathrm{~m}$, whereas water depths increased to as much as $1000-2000 \mathrm{~m}$ over the next 12 to $17 \mathrm{~m}$ of the sedimentary section. No obvious signs of reversal in subsidence are seen; if uplift/sea level regression did occur, it either imparted no marked change in the depositional environment or occurred at intervals not sampled by the coring or not studied by the writer.

Date of Initial Receipt: March 23, 1982 

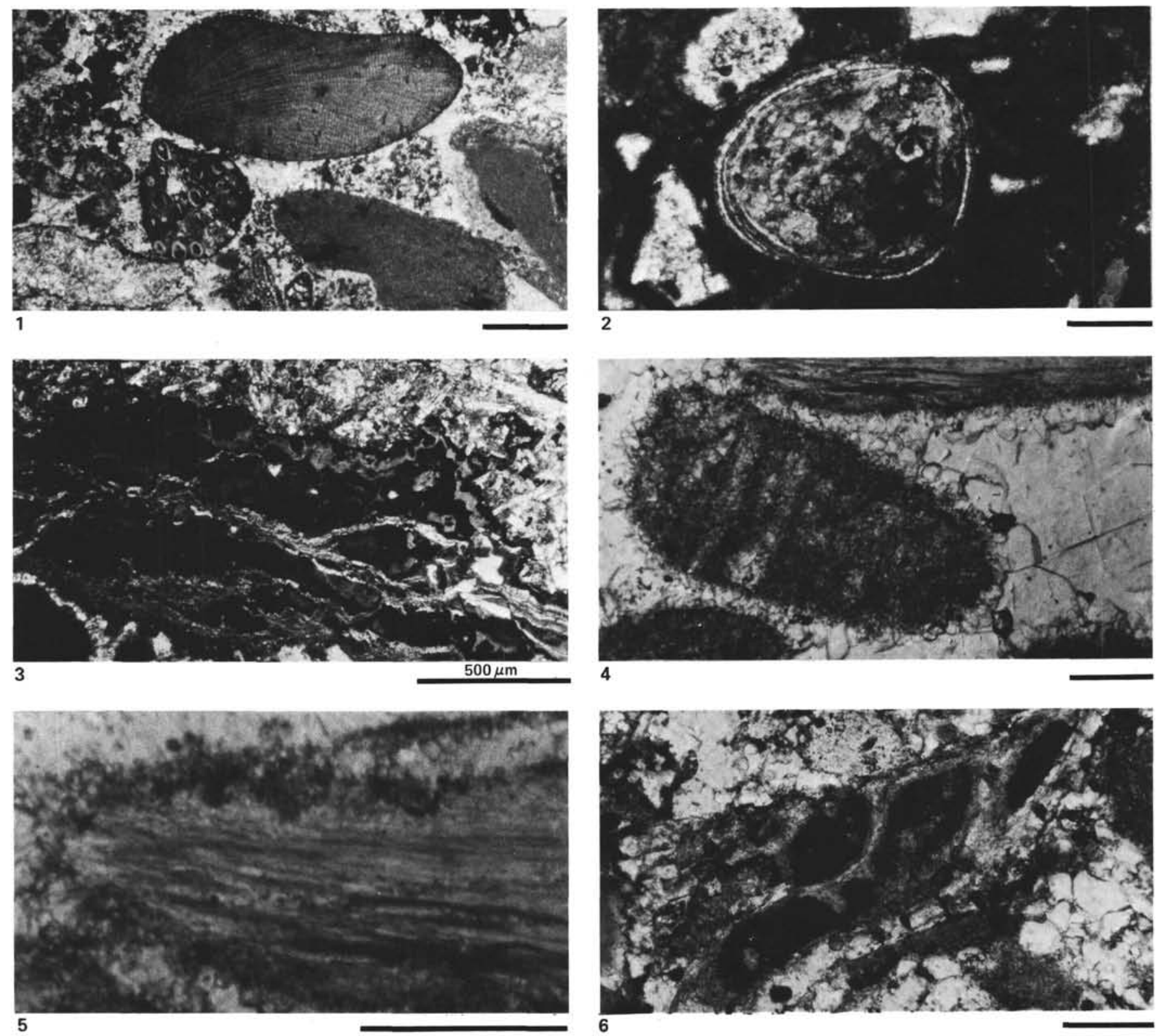

Plate 1. Refracted-light photomicrographs of samples from Hole $516 \mathrm{~F}$. All scale bars equal $100 \mu \mathrm{m}$ unless otherwise indicated. 1. Coralline algal fragments and lithoclast in micritic cement; Sample 516F-126-1, 0-4 cm. 2. Pseudo-ooid; actually a filled vesicle; Sample 516F-126-2, 37-39 $\mathrm{cm}$. 3. Calcite-filled veins in volcanic rock fragments; Sample $516 \mathrm{~F}-126-2,37-39 \mathrm{~cm}$; scale bar $=500 \mu \mathrm{m}$. 4. Rim cement around mollusk (upper) and foraminiferal (center) fragments. This plus the clear blocky intergranular cements suggest the absence of a sedimentary matrix and therefore a higher energy (open shelf?) depositional environment; Sample $516 \mathrm{~F}-125-2,11-14 \mathrm{~cm}$. 5. Enlargement of the mollusk grain in Figure 4 ; note the highly bored nature of the shell fragment; Sample 516F-125-2, 11-14 cm. 6. Glauconite-filled foraminiferal (?) fragment; the absence of shallow-water fossils and the presence of a more micritic matrix also suggest deposition on the upper slope; Sample 516F-124-2, 64-70 $\mathrm{cm}$. 